\title{
Szwajcaria w czasach zarazy ${ }^{1}$
}

\section{Odcinek 1: Twierdza zostaje zdobyta}

\section{Wuhan. Miasto w środkowych Chinach. Tak daleko, a tak blisko}

Zdjęcia z Wuhanu stały się naszym chlebem powszednim. W Szwajcarii oglądał je każdy. Od grudnia, dzień w dzień, telewizja pokazywała opustoszałe ulice miasta i ubranych w kombinezony ratowników medycznych. Do tego astronomiczne liczby ofiar. Tak samo abstrakcyjne jak i miasto, o którym wcześniej wielu nie słyszało.

Pod koniec stycznia przyszedł czas na Włochy, kraj lepiej nam znany. Pierwsi zakażeni, a potem tragiczna eksplozja zachorowań. W telewizji zdjęcia z przepełnionych szpitali w Lombardii i raporty o lekarzach, którzy nie dają sobie rady. Niby bliżej, ale wciąż abstrakcja.

A potem w Szwajcarii pojawiła się pierwsza osoba, u której wykryto COVID-19. 25 lutego, czas karnawału. To jednak nie był żart. Właśnie mija miesiąc.

\section{Abstrakcja trwa}

Patrząc na historię epidemii wirusa COVID-19 wśród Helwetów, można rzec: dobre złego początki. Kiedy gruchnęła wiadomość, że w Wallis wykryto „pacjenta zero", niewiele osób wzięło to serio. Wśród moich najbliższych zaobserwowałam

${ }^{1}$ Cykl opublikowany na blogu I'm not Swiss: Szwajcaria inna niż myślisz Agnieszki Kamińskiej, https://iamnotswiss.blog. 
zdziwienie, że i tutaj wirus dotarł. Oznak niepokoju brak. Choroba wciąż wydaje się być daleko.

Kolejne dni przynoszą wzrost zachorowań. Towarzyszy im wiadomość, że osoby, które miały kontakt z zakażonym, objęte są kwarantanną. Ta mrówcza, niemalże detektywistyczna praca poraża skrupulatnością. Wiara w system jest duża: "Jeśli mieliśmy kontakt z kimś chorym (ale niby gdzie?), lekarz sam się po nas zgłosi”. Posługując się tą logiką, na Literaturfest w Lucernie dobrowolnie wpisuję się na listę gości i podaję numer telefonu. Co tam ochrona danych osobowych! Gdyby odkryto, że inny miłośnik książek miał wirusa, lekarze mnie znajdą.

Rząd zaleca unikać imprez masowych. Te powyżej 1000 osób są powoli odwoływane. Rozdanie Swiss Music Awards w Lucernie odbywa się przy połowie sali. Kiedy odwołują maraton narciarski w Engandynie, Narzeczony i koledzy narciarze łapią się za głowę. W Bazylei nie będzie też karnawału. W kraju, w którym rzadko coś się odwołuje, ludzie się dziwią, ale do paniki im daleko. Przesadna ostrożność - dla jednych. Odpowiedzialny krok - dla innych. I jedni, i drudzy zakładają, że to rozwiąże problem.

W pociągach tłok. Rząd zaleca unikać transportu publicznego, ale jak to zrobić w kraju, gdzie miliony dojeżdżają do pracy i szkoły. Poza tym to pracodawca ma zdecydować o przejściu w tryb home office. I tak, czekając na decyzję „Z góry”, krążę między Lucerną, Bernem i Zurychem. Wdycham morowe powietrze i nasłuchuję, czy ktoś kaszle. Razem ze mną słucha cały wagon, pełen ludzi skazanych na dojeżdżanie. Może tylko zrobiło się ciszej. Nie ma już głośnych rozmów przez telefon - tak jakby, żeby zminimalizować ryzyko wchłonięcia wirusa, pasażerowie przestali się odzywać.

Nowy termin, social distancing, powoli wkracza do mediów, ale w pociągach tłok jak zawsze. Apele o trzymanie odstępu pasażerowie przyjmują zakłopotanym uśmiechem: „W godzinach szczytu nawet sardynki w puszce mają luźniej. Mam powiedzieć, że puste miejsce obok jest zajęte?”.

\section{Bierzemy to na lekko}

Po dużych imprezach przyszedł czas na mniejsze. Tokarczuk nie przyjedzie do Szwajcarii. Konferencja w Zurychu odwołana. Wystawa, której jestem kuratorką, przesunięta na za rok. W kalendarzu robi się pusto.

Szwajcarzy przyjmują to ze zdziwieniem. „Jak to, wystawa miała być w maju? Do tego czasu będzie po wszystkim". Na wieść, że Azja Środkowa - Kazachstan i Mongolia - do których miałam jechać na wiosnę, wprowadzają restrykcje wjazdu, znajomi robią wielkie oczy. Tak jakbyśmy to tylko my w „rozwiniętej” Europie mogli komuś pozwalać wjechać albo nie. Polska już zamknęła granice. Szwajcaria nadal jest otwarta. 
Apele o social distancing przynoszą niewiele. W Nordbrücke, ulubionej knajpie w Zurychu, tłok tak gęsty, że niemal intymny. Dopiero co poznane osoby wylewnie całują mnie na pożegnanie. To jeszcze nie dekadencja życia na tonącym statku, raczej chęć pokazania, że nic nas nie rusza. Albo błogie myślenie, że kryzysy to gdzieś indziej, ale nie tu.

W pracy po staremu. Tylko kolega z Niemiec mówi, że jego matka ma kwarantannę. Córka znajomej też. Oho, więc to już nie tylko choroba telewizyjna. Zdarza się w prawdziwym życiu. Dla innych to nadal abstrakcja. Na seminarium w Bernie student kaszle, jakby miał suchoty. „To tylko przeziębienie”, tłumaczy. Za parę dni okaże się, że następnych zajęć nie będzie. Przynajmniej nie twarzą w twarz.

Pierwszy raz zauważam, że pociąg powrotny do Lucerny jest dość pusty. Może dlatego, że to osobowy przez Entlebuch? Przy oknie Japonka w szaliku naciągniętym na twarz. Poza tym cisza i spokój. „Gdyby dojeżdżanie do pracy zawsze było takie komfortowe!", myślę, patrząc na zielony krajobraz za oknem. Na szosie korek: ludzie wciąż dojeżdżają, tyle że samochodem.

Pod koniec tygodnia przychodzi fala wiadomości z różnych kantonów. Politechnika w Zurychu zamyka podwoje. Uniwersytet w Lozannie i Lucernie też. Berno próbuje systemu rotacyjnego: połowa studentów na sali, druga w domu. Uniwersytet Zuryski uparcie chce dalej funkcjonować. Mimo tego, że to właśnie on był prekursorem w rozsiewaniu wirusa w tym mieście. W końcu i Zurych się poddaje.

Lubię pracować $\mathrm{w}$ domu, ale na fajrant dobry jest sport. Od paru dni z ciekawością obserwuję strony klubów fitness. Wszystkie otwarte, mimo że są miejscem intensywnej interakcji społecznej, gdzie różne rzeczy można złapać W piątek wieczorem idę do Fitnesspark Allmend. „Państwo są otwarci?” „Oczywiście, do 22.00”, słyszę w recepcji. „Mam na myśli koronę”. Zaskoczenie. W środku zalecają trzymać dystans (sala i tak jest przepełniona) i wymyć po sobie sprzęt. Ale to robi się tu tak czy siak. Za dwa dni przyjdzie wiadomość, że z fitnessem koniec.

A co z życiem towarzyskim? W weekend mamy zaplanowaną kolację dla znajomych. Bigos stoi już od kilku dni na balkonie. Goście stawili się prawie wszyscy. Przy drzwiach zamiast wylewnych powitań rozdzielamy komendy: zdjąć buty, powitanie łokciem albo skarpetką, potem mycie rąk. Każdy ma pilnować widelca i szklanki. Goście są zirytowani. Na hasło: „Umyj ręce” słyszę: „Myłem w domu”. Posłuch w narodzie jest ograniczony.

Korona jest jednym z wielu tematów przy stole. Głównie w kontekście tego, gdzie można pojechać na narty. Tu zamknięte, tam zamknięte. Ponoć w Berner Oberland niektóre trasy są otwarte. Ekologicznie uświadomieni Szwajcarzy mówią, że nareszcie mniej samolotów i środowisko będzie czyściejsze. Tylko że gospodarka straci. Wciąż są to rozmowy abstrakcyjne, wokół tematów-haseł: „klimat”, „gospodarka”. Na konkrety trzeba poczekać.

W sobotnią noc wykonuję rundę rowerem po mieście. Liczba osób, które mogą legalnie przebywać w jednym miejscu, stopniała już do 50. Mimo to ży- 
cie nocne kwitnie. Przed przepełnionym klubem wytacza się z taksówki zalany gość. Na parkiecie tłoczy się gęsta masa ludzi. W oknie innej knajpy napisane: „No Corona. Only local beer”. „Klient nr 51 nie zostanie obsłużony”. Jak to wygląda w praktyce, nie sprawdziłam.

Przynajmniej pogoda dopisuje. Góry i świeże powietrze wciąż są dozwolone (Tatry i Mount Everest jednak zamknęli). Kolejki linowe wprawdzie nie działają, ale za to gastronomia ma się jak najlepiej. Uprzejmy komunikat w górskim Beizu mówi, że powyżej 50 osób lokal obsłużyć nie może, ale każdy stolik jest zajęty. Warunki do dalszego rozprzestrzeniania się wirusa można uznać za dobre.

\section{Panika}

W poniedziałek telewizja podała, że w ciągu jednej doby zanotowano wzrost zachorowań o ponad 800 osób. Szwajcaria wprowadza stan wyjątkowy. To sielankowe sceny ze szlaków narciarskich skłoniły rząd do akcji. Zważywszy brak solidarności między kantonami (vide: próba zarobienia na narciarzach $\mathrm{z}$ sąsiednich kantonów), teraz to państwo przejmuje dowodzenie.

Szlaban dostają lokale, które nie są „niezbędne do przeżycia” (dla klientów, dla właścicieli sprawa wygląda inaczej). Otwarte będą spożywczaki, apteki, stacje benzynowe. Bez reszty obywatel musi się obejść. Do fryzjera nie pójdzie, butów nie naprawi. Sobotni targ w Lucernie odwołany do... odwołania. Zarządzenie wchodzi w życie we wtorek. Nieświadoma niczego, w poniedziałek idę do biblioteki pożyczyć książkę o ogrodnictwie (czuję, że wkrótce będę mieć czas na uprawianie ogródka). Bibliotekarka schowana za warstwą pleksi uśmiecha się blado. Dzień później biblioteka zostaje zamknięta. Podobnie jak inne instytucje kultury.

Naród coś musi robić, więc biegnie do spożywczego. Puste półki w Coop i Migros to nie fake news. Zieją w nich dziury, szczególnie rażące w zestawieniu z ogólnym dobrobytem. Spaceruję między regałami, tropiąc, co kupuje Szwajcar na czarną godzinę (für regnerische Tage po szwajcarsku). Na regale z mąką pusto. Nie ma makaronu i sosu pomidorowego. Ryż też wygląda blado. Sektor jajeczny opustoszał (Czy to już na Wielkanoc? Chyba tak, bo widzę, jak jakiś gość niesie koszyk wielkanocny „made in Migros”). Po papierze toaletowym nie został ślad.

$\mathrm{Za}$ regałem, gdzie kiedyś stało müesli, czai się facet $\mathrm{z}$ aparatem. „Fotografuje pan pustkę?”, zagajam. „To trzeba udokumentować”, mówi. „Za dziesięć lat pokażę dzieciom. Inaczej mi nie uwierzą”. Jako Polka rocznik '76 myślę: „Oj, szczęśliwy narodzie, co po raz pierwszy widzisz puste półki!”. Makaron z sosem to dieta studencka. Każdy ugotować potrafi. Ale mąka? Czyżby każdy Szwajcar umiał piec chleb? Pewnie raczej pizzę. Telewizja podaje, że piekarnie ponoszą straty. Czyżby ludzie przestali kupować chleb? Jedzą już tylko ryż i makaron?

Kombinacja tego, czego „nie ma”, jest frapująca. Za kryzysu kubańskiego, berlińskiego i wszystkich innych dziadkowie chomikowali mąkę, cukier, spirytus 
i inne cuda. W późniejszym PRL-u było tak samo. Ale wtedy niewiele było. W bogatej Szwajcarii myślałam, że ludzie będą kupować wino i łososia, coś lepszego niż mąkę typ 405. Okazuje się, że nawet w kraju dobrobytu naród władzy nie ufa i zaopatrzyć się musi.

Idę wysłać rodzicom paczkę. W niej PADMA Grippe-Formel. Numerkomat na poczcie nie działa. To logiczne: hasło „be in touch” nacechowane jest teraz negatywnie. Na podłodze narysowane krzyżyki, gdzie można stać (dla dowcipu wolałabym raz kółko, raz krzyżyk). Poczciarka, bezpieczny metr od lady, kiwa na mnie głową. Zaczynamy taniec „krok w przód, krok w tył”. Podchodzę, „Grüezi”, kładę paczkę, krok w tył. Kobieta podchodzi, patrzy na adres. „Do Polski nie wysyłamy". Znowu krok w tył. Teraz ja do przodu. Biorę paczkę, dziękuję, wychodzę. Przy sąsiednim okienku klientka z „grupy ryzyka”, na oko 70+. Rozmawia, śmieje się, nie chce odejść. Kto jak kto, ale emeryci w przestrzeni publicznej widoczni są jak nigdy.

Wiedza o sytuacji w kraju jest znikoma, ale wszyscy wiedzą, że kraj przygotowany jest na wirusa. Oglądam konferencję prasową. Daniel Koch, państwowy ekspert od chorób zakaźnych - przyciśnięty przez dziennikarza - przyznaje, że służba zdrowia ledwo dyszy. Wolnych łóżek na intensywnej terapii niewiele. Pytam znajomych Szwajcarów, jak myślą, ile. Rzucają: „1500?” Nie, 160. Są zdumieni. Telewizyjna propaganda mycia rąk też nie działa: wielu wciąż trudno zrozumieć, że wirus przenosi się przez dotyk. Klamki, pieniędzy, czegokolwiek. Ekspedientki w Kriens, miasteczku, gdzie mieszkam, wydają resztę bez rękawiczek, a sklepowy podaje mi ser, do spróbowania, ręką. Zaufanie społeczne na prowincji jest duże. Chociaż u mojego dentysty w niewielkim Sarnen zniknęła półka z gazetami: na papierze COVID-19 też umie przeżyć.

Bez tłumu turystów w Lucernie można spokojnie popatrzeć na Kappellbrücke, główną atrakcję miasta. Normalnie, w czasach nie-zarazy, omijasz to miejsce szerokim łukiem. Na moście zaczepia mnie facet: „Jakie pustki! Kto by pomyślał?”. Dobre pytanie. Z tym że Światowa Organizacja Zdrowia ogłosiła stan pandemii już 11 marca, a zdjęcia z Wuhanu oglądamy całą zimę. „No ale turystów z Chin nie ma!", facet zauważa przytomnie. Obawiam się, że wielu myślało podobnie: skoro Chińczyk nie przyjeżdża, to choroby nie przywlecze. A że Szwajcar jeździ po świecie i coś może przywieźć, mniej nam się w głowie mieści. Zdumiewające, że mimo globalizacji i bycia w (prawie) sercu Europy, Szwajcaria nadal czuje się bezpiecznie schowana w górach. Twierdza nie do zdobycia. A jednak, koronie się udało.

Przy kolacji w środę konsternacja. Główne wydanie wiadomości spóźnia się o 17 minut. Tak po prostu, jak mówi komunikat, „z przyczyn technicznych”. Patrzymy po sobie. Takie rzeczy się tu NIE zdarzają.

W czwartek wieczorem zapalam świeczkę na balkonie. Mówili w telewizji, żeby zapalić, na znak solidarności z tymi, co siedzą w domu sami. Wyglądam przez wszystkie okna, widzę zaledwie dwa światełka. Ja mam to w kościach, jesz- 
cze z PRL-u, te akcje okienne. „Zamrugaj lampą, jak słuchasz Podziemnego Radia Solidarność”. Następnego dnia o 12:30 ludzie klaszczą, jako umówiony znak podziękowań dla tych, co niosą pomoc medyczną. Może nie trwa to zalecanej przez media minuty, ale jednak. Społeczeństwo musi się jeszcze rozruszać.

$\mathrm{U}$ Narzeczonego home office nie ma. W piątek wraca z pracy zdruzgotany. Ponoć jego fizjoterapeuta jest koronapozytywny. Pierwszy raz widzę przerażenie na jego twarzy. Jeszcze mu nie wspomniałam, że koleżanka z biura leży w łóżku z kaszlem i gorączką. Niedawno była w Paryżu. „To pewnie Corona”, napisała na WhatsAppie. Ale takich jak ona się nie testuje. „Cóż, francuskie metro to może nie był najlepszy pomysł”, rzuciła, nie bez francuskiej elegancji.

\section{Poczekamy, zobaczymy}

Zakazu wychodzenia z domu na razie nie będzie. Szwajcar musi się ruszać. Politycy mówią, że to jedna z podstawowych wolności. Poza tym zapobiegamy w ten sposób przemocy domowej. A ja myślałam, że w Szwajcarii przemocy domowej brak. Kto wie, ile jeszcze ciekawego nauczymy się dzięki wirusowi.

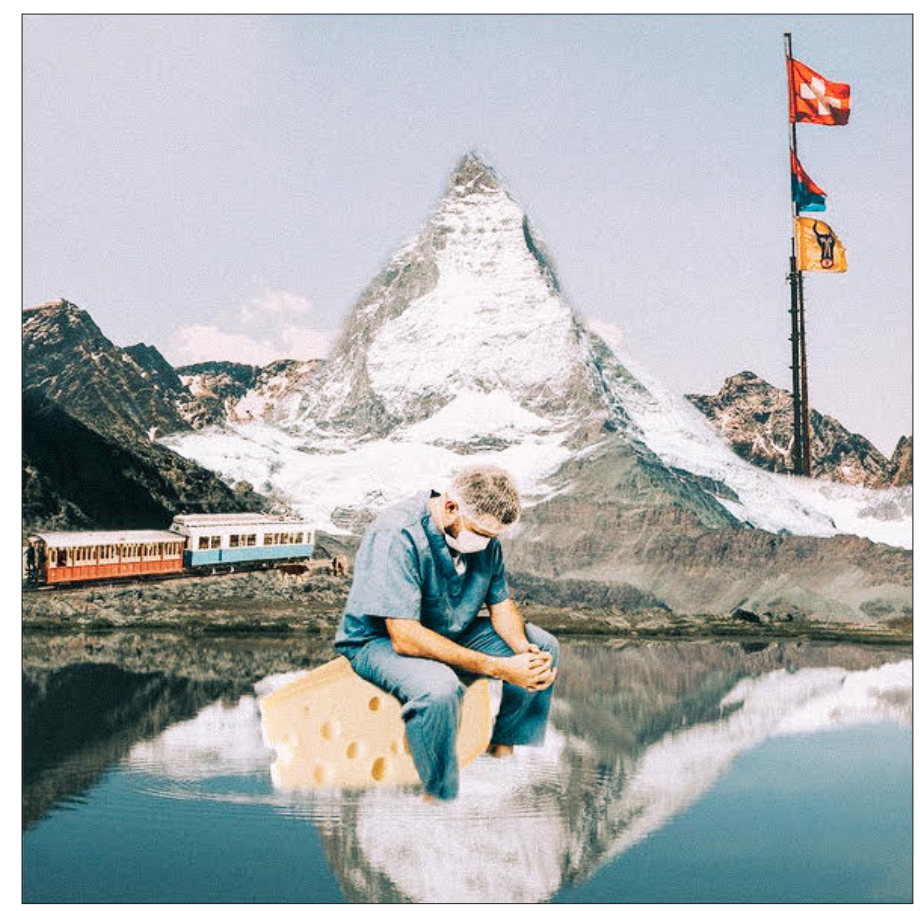

Ilustracja 1: autorka Emilia Stasiak / quarantinecollages 


\section{Odcinek 2: Świat kurczy się do minimum}

W okolicy wylądował statek kosmiczny. Jego ponury cień kładzie się na podalpejskie ulice. Drzwi statku są zamknięte. Kosmici jeszcze nie zeszli na ziemię. Nie wiadomo, czego chcą, ale lepiej ich nie prowokować. Mniej więcej taką atmosferę mamy w Kriens. Ludzie chodzą jak na palcach. Jest w nich coś nienaturalnego.

\section{Sytuacja jest poważna}

Grozę sytuacji czuje się w sklepach. Sobotnie zakupy przypominają sceny z filmu science fiction. Zanim otworzą się główne drzwi, musisz odczekać na ulicy. Potem dwa kroki do żółtej linii. Zamaskowana pracownica sklepu klika coś na aparacie, jakby liczyła pasażerów wsiadających na pokład. Kiwa głową, możesz iść dalej. Dalej, czyli do kolejnej linii. Potem następnej i następnej. „Ile może być osób w sklepie”, pytam kontrolerkę ruchu sklepowego. „Teoretycznie 150, ale wszyscy idą na warzywa, więc mieści się mniej”. Faktycznie, między ziemniakami a pomidorem ukrywa się facet z kabelkiem w uchu. Czujnym okiem liczy kupujących. Kiedy zagęszczenie między straganami się rozrzedzi, kolejna osoba może wejść na pokład.

Nie można szwendać się między półkami, czekając na kulinarne olśnienie. Z głośników, z których na wiosnę płyną reklamy ravioli z czosnkiem niedźwiedzim i sosu hollandaise, słychać: „Prosimy kupować szybko i przemyślanie. W ten sposób umożliwimy innym skorzystanie z usług sklepu”. Ale nie wszystko jest na sprzedaż: sprzęt AGD, zabawki i kilka innych regałów obwiązanych jest taśmą. „Nie są niezbędne do życia”, informuje ekspedientka. Przed wyjściem kolejka do mycia rąk. „Ciekawe, kiedy moje palce będą świecić jak u E.T.”, myślę, wcierając w skórę płyn do dezynfekcji. Butelka z nim króluje przy drzwiach, przywiązana sznurkiem do stolika. W kraju, gdzie sklepy zostawiają na ulicy palety pelargonii i nikt ich w nocy nie kradnie, okazuje się, że jest coś, co podważa wiarę w uczciwość obywateli. A może powab płynu do dezynfekcji mocniejszy jest niż morale?

W czasie wojny trzeba sobie radzić. A Szwajcaria jest w stanie wojny z wirusem. To sformułowanie powtarza się w wypowiedziach ekspertów: od medycyny, gospodarki, życia społecznego. Wszyscy podkreślają: takiej sytuacji Szwajcaria nie widziała od lat. Mobilizacja wojska (żołnierze pomagają służbom medycznym) pierwsza w tej skali od drugiej wojny światowej. Kontrole na granicach, kłopoty $\mathrm{z}$ aprowizacją. Nawet wiosenny rytuał Sechseläuten $\mathrm{w}$ Zurychu, stały punkt w kalendarzu miasta, został odwołany. Pierwszy raz od czasu wojny. Mimo że dla Szwajcarii wojna jest abstrakcją, porównania te mają wielką moc.

To, że ludzie pojęli grozę sytuacji, jest zasługą telewizji. Teraz oglądają ją wszyscy, nawet przeciwnicy płacenia abonamentu. Sobotnie wiadomości osią- 
gają szczyt dramatyzmu. Pokazują nagranie ze szpitala w Romandii. Lekarze dzwonią do kobiety, której matka leży - w stanie agonalnym - na ich oddziale. Córka dzielnie przyjmuje tragiczną wiadomość - widzimy jej twarz na ekranie telewizora. Zaraz potem relacja $\mathrm{z}$ anonimowego szpitala we Włoszech. Rzędy łóżek. Na łóżkach zaintubowani pacjenci podłączeni do skomplikowanej aparatury. Obok lekarze ubrani, jakby usuwali skutki eksplozji w Czarnobylu. Kolejny materiał z Madrytu: kawalkada samochodów wiezie ciała do hali hokeja zamienionej w kostnicę. Komentarz mówi, że na COVID-19 umiera się samotnie. Nawet na pogrzebie nieboszczyk jest sam.

Po wiadomościach telewizja podaje środek łagodzący szok. Program Zäme dihei, czyli Razem w domu. Różni ludzie, bardziej i mniej znani, na kanapie albo za kuchennym stołem, opowiadają o życiu w samoizolacji. Taki Big Brother, ale w innym stylu. Telewizja straszy, ale i uspokaja. Zakazu wychodzenia nie będzie, ogłasza minister zdrowia. Ale wychodzić nie należy. Kanton Uri zbytnio wysunął się przed szereg, wprowadzając - z czystej troski o mieszkanców - zakaz wychodzenia dla seniorów. Szybko dostał po łapach, bo taki zakaz jest niekonstytucyjny. Mimo stanu pandemii rząd liczy na rozsądek obywateli. To rozsądek i samodyscyplina mają być kluczem do sukcesu.

Kraj podzielony jest jednak w opiniach. W Romandii i Tessynie ludność domaga się radykalnych kroków, włącznie z zakazem wychodzenia $\mathrm{z}$ domu. W niemieckojęzycznych kantonach panuje większy relaks. Albo zaufanie do rządu jest tu większe, albo fakt, że ofiar jest mniej, sprawia, że ludzie biorą chorobę mniej serio. A ona jest tuż-tuż. Urodziny kolegi. Narzeczony dzwoni z życzeniami. „Nie, nie ma imprezy. Nastroju zresztą też nie", kolega mówi ponuro. Obydwoje rodzice są pozytywni. Byli na nartach w Gryzonii. Po powrocie zadzwonił znajomy, z którym spędzali ferie. Wykryto u niego wirusa. Następnego dnia matka jest już na intensywnej terapii.

\section{Społeczeństwo się organizuje}

Liczba zachorowań skacze o kilkaset przypadków dziennie. Za jakiś czas przestaną podawać te liczby w mediach. Za to jak grzyby po deszczu pojawiają się apele o pomoc. Szpital kantonalny w Lucernie poszukuje wszystkich: od medyków po niewykwalifikowanych wolontariuszy. Zgłaszam się następnego dnia. Ze względu na liczbę zgłoszeń nie przyjmują więcej ochotników. Miasto Kriens też szuka.

Spotkanie informacyjne odbywa się w kościele, tymczasowo zamienionym w punkt dowodzenia. W nawie głównej, rozsadzeni daleko od siebie jak na egzaminie maturalnym, chłoniemy informacje, co wolno, a czego nie. Nie podajemy rąk. Nie wchodzimy do mieszkania. Robimy, co trzeba: zakupy, wynieść śmieci i surowce wtórne (choćby świat się walił, w tej dziedzinie musi panować porzą- 
dek), wyjść z psem. Zakupy tylko podstawowe, żadnego preppingu. Gdyby ktoś zażyczył sobie pięć kilo cukru i kopę jaj, mamy meldować do centrali.

Kilka dni później dostaję pierwsze zlecenie: odebrać leki z przychodni. Tam prawie apokalipsa. Emeryci szturmują recepcję. Kobieta, której dostarczam leki, przyznaje, że ma zapas na parę miesięcy. Nie dziwię się, że w aptekach wprowadzono limit na aspirynę i tabletki przeciwbólowe. Kolejne zlecenia to zakupy spożywcze. Listy zakupów są fascynujące. Sałatka makaronowa, parówki, purée ziemniaczane. Widać, że samotny mężczyzna, który gotować nie chce albo nie umie. Dla takich osób gazety publikują teraz „ABC gotowania dla dorosłych”. Inni nasi podopieczni mają bardziej rozbudowane plany. Cztery sznycle, ale nie grubsze niż na centymetr (mają być ucięte przy mnie, na stoisku masarskim, jak zapisane jest w instrukcji), fenkuł, oliwki i rukola, jogurt bez laktozy. Do tego wskazówki, do którego sklepu pójść. Niektórym jest wszystko jedno. Inni zaznaczają, że do delikatesów. Przed mieszkaniem, gdzie deponuję zakupy, znajduję kopertę. W niej podziękowania i 5 franków, żebym miała „na kawę”. Oczywiście, jak otworzą kawiarnie. To prędko nie nastąpi.

Naród popiera decyzje rządu. Może tylko fakt, że sklepy ogrodnicze są zamknięte, trochę denerwuje. No bo siedzisz w domu, jest wiosna, to można by chociaż kwiatki posadzić na balkonie. No ale właśnie nie można. W osiedlowym sklepiku emeryt w kaszkiecie i swetrze na guziki rozpaczliwie rozgląda się po regale z jarzyną. , Sadzonek szukam”, mówi z mało szwajcarskim akcentem. Żona go wysłała. „Przykro mi, sadzonek nie mamy”. „To może chociaż cebula?” Mężczyzna nie chce wracać z pustymi rękami. „Z tej sklepowej i tak nic panu nie wyrośnie”. Ta pustynia konsumpcyjna jest sucha tylko pozornie. Pod powierzchnią tego, co wygląda na przerwę od zakupomanii, bujnie kwitnie podziemie. Kto umie nawigować online, kupi wszystko. Sadzonki i ziemię do kwiatków też. Na naszej ulicy samochód firmy kurierskiej jeździ tam i z powrotem. Poczta wprowadziła już ograniczenia na dostawę paczek. Sortownie pękają w szwach, a listonosze narzekają na bóle krzyża.

Zamknięty fryzjer też irytuje. Warstwa żelu we włosach mężczyzn wyraźnie się zwiększa, a odrosty na głowach kobiet dekamuflują ukrywaną siwiznę. Narzeczony męczy mnie, żebym go ostrzygła. Bronię się jak mogę: „Zobacz, pani Sommaruga też ma fryzurę na Limahla. To hit tej wiosny”. Od początku podejrzliwie obserwuję członków rządu: czy mają prywatnego fryzjera, podczas gdy naród cierpi na permanentny bad hair day? Okazuje się, że w porządnej demokracji ludzie - pod tym względem - naprawdę są równi.

Obowiązkowe dwa metry dystansu powoli wchodzą w społeczny krwiobieg. $\mathrm{Na}$ chodniku sąsiedzi omijają się szerokim łukiem. Nastolatki jedzą lody przed sklepem, na dwóch końcach ławki, jakby się właśnie pokłóciły. Dwóch facetów na murku pije trzecie piwo. Między nimi dwa metry. Nasza comfort zone rozszerza się do niekomfortowych rozmiarów. Jedni uśmiechają się skrępowani, robiąc unik na trawnik. Inni odwracają oczy. Ci, co się zamyślą i zapomną o nowym 
savoir-vivre, usłyszą bolesną uwagę pod swoim adresem. „Proszę się ode mnie odsunąć!”. Taka bezpośredniość (bez słynnego koniunktiwu) jest w Szwajcarii czymś niesłychanym.

Przez okno mieszkania słychać serenady: kosiarkę sąsiada i karetkę na sygnale. Czy mi się zdaje, czy tę drugą słychać teraz częściej? Na karetkę zaparkowaną dwa domy dalej wpadam, wracając z zakupów. Zimny dreszcz przebiega mi po plecach. W domu Narzeczony wita mnie z plastikową butelką w ręce. „Zwinąłem z pracy”, oznajmia rzeczowo. „Zdezynfekuj”. Do kompletu maseczka. Od tej pory na zakupy chodzimy zamaskowani. Bonnie and Clyde epoki COVID-19.

\section{Taki mały kraj}

Po pustych ulicach dobrze jeździ się samochodem. Zwłaszcza jeśli od dawna nie siedziało się za kółkiem. Codziennie wymykam się z domu zrobić kurs po okolicy. Miejskie chodniki są puste, ale tam, gdzie zaczyna się życie prywatne, panuje większy luz. Schowani na opuszczonym placu zabaw młodzieńcy palą marihuanę, a grupa emerytów delektuje się cuvée na pikniku na pobliskiej górce. Życie balkonowo-ogródkowe kwitnie. U sąsiadów grill jest codziennie. Są goście, piwo i kiełbaski. Trudno się dziwić, w sklepach zaczynają się promocje.

Wielkanoc zbliża się wielkimi krokami. Czas rodzinnych wycieczek i wizyt w kościele. Żeby zniechęcić ludność do spacerów, Lucerna planuje zamknąć główną promenadę. To samo zrobił już Zurych. Miasto Zug wprowadziło patrole konne, które rozganiają spacerowiczów. Nad jeziorem w Lucernie wciąż widać amatorów pięknych widoków. Tu ktoś z psem, tam rodzina z lodami. Na trawniku przed zamkniętym hotelem piętrzy się góra zdemontowanych ławek. Człowiek, jak gołąb, lubi usiąść. Żeby go do tego zniechęcić, miasto zarządziło demontaż. Kościoły są otwarte, mszy jednak się nie odprawia. Woda święcona wyparowała. Ze względów bezpieczeństwa, jak czytam na drzwiach jednej świątyni. Proboszcz zachęca do modlitwy za tych, których dotknęła tragedia. I informuje, że pogrzeby odprawia się bezpośrednio na cmentarzu, tylko w gronie najbliższych. Fakt, nekrologi w gazecie opatrzone są komentarzem: „Pogrzeb w gronie najbliższych. Msza w intencji odbędzie się w terminie późniejszym”. Czyli po zakończeniu stanu wyjątkowego.

Zapuszczam korzenie w domowym biuro-areszcie i szukam dobrych stron życia w samoizolacji. Pasjami nadrabiam zaległości kulturalne. Moje ulubione radio przestawiło się na szwajcarską muzykę (tę współczesną, nie mam na myśli jodłowania). To w ramach wspierania miejscowych artystów. Całymi dniami puszczają szwajcarskie the best of $\mathrm{z}$ kolejnych dekad. W innej sytuacji nie miałabym okazji ich poznać. Szwajcarscy pisarze czytają fragmenty książek online. Kilka szwajcarskich filmów obejrzę w internecie, gdzie teraz są dostępne legalnie i tanio. 
Ucieczka w to, co nam znane, jest wygodnym rozwiązaniem: dodaje siły w czasie kryzysu, ale zawęża horyzont odczuwania. Szwajcarska telewizja informuje głównie o sytuacji w Szwajcarii. Dodatkowo o Włoszech, Hiszpanii i innych „ważnych” sąsiadach. Europa nie-Zachodnia w mediach praktycznie nie istnieje. Od wybuchu pandemii w wiadomościach padło kilka słów o Chorwacji, ale to z okazji trzęsienia ziemi. Z Kosowa nadali relację o kryzysie rządu. No i z Węgier, kiedy Viktor Orbán, pod przykrywką pandemii, podarował sobie władzę absolutną. Inne kontynenty też prawie nie istnieją. Zglobalizowany świat skurczył się nam do minimum.

Tymczasem w sklepach rzucili nowy towar. Szwajcarskie flagi z hasłem w czterech językach: „Razem odpowiedzialnie i solidarnie”. Solidarna wydaje się być nasza sąsiadka, kiedy ogłasza całkiem na poważnie: „Wszyscy powinni się pozarażać. W ten sposób się uodpornią”, „A ci, co przy okazji umrą?”, pytam. „Przecież nie umiera aż tyle. Włosi są po prostu gorzej zorganizowani”. Podobną opinię słyszę wielokrotnie. Poza tym „świat jest przeludniony, więc lepiej, jak liczba ludności się zmniejszy”. Włosy stają mi dęba. „A gdyby to o twoich rodziców miałaby się ona zmniejszyć?" W tym samym czasie, w Indiach, tysiące ludzi maszerują pieszo do domu (bo pociągi zjechały na bocznicę), a moje kuzynki w Lubelskiem szyją w domu maski (bo - to nie prima aprilis - w szpitalach ich zabrakło). Czy krótkowzroczność to konieczny efekt uboczny pielęgnacji własnej tożsamości?

Choroba jakby powoli traciła walor grozy. Być może ludzie uodporniają się psychicznie na wirusa? Zdiagnozowanych jest już 24000 . Tych liczb telewizja już jednak nie podaje. O zdrowiu mówi się już coraz mniej. Więcej o gospodarce i jej ratowaniu. Kolejne branże zgłaszają swoje roszczenia. Fryzjerzy, przedszkolanki, każdy, kto może. Nawet kolej chce odszkodowań za straty spowodowane brakiem pasażerów. $Z$ etapu siania przestrachu przeszliśmy na etap radzenia sobie $\mathrm{z}$ kryzysem. Rząd obiecuje, że pod koniec kwietnia rozluźni uścisk. Ale warunkiem jest to, by w Wielkanoc zostać w domu. Dla Szwajcarów, którzy w święta masowo ruszają na południe kraju, to brzmi jak asceza.

\section{Święta, święta i po świętach}

Wielkanoc minęła spokojnie. W sklepach kolejki. U sąsiadów grill jak zawsze. W naszym ogródku pierwsze rzodkiewki nieśmiało wypuszczają listki. Zaaferowana wirusem nie zauważyłam, że od kilku tygodni nie padał deszcz. „To straszne. Znowu będzie susza", zagaduje mnie sąsiad z przepisowych dwóch metrów. Po chwili się miarkuje. „Pewnie uważasz, że my w Szwajcarii nie mamy problemów?”

Po świętach rząd ogłosił plan wychodzenia z kryzysu. Krok po kroku. Będzie można kupić kwiatki i pójść do fryzjera. 


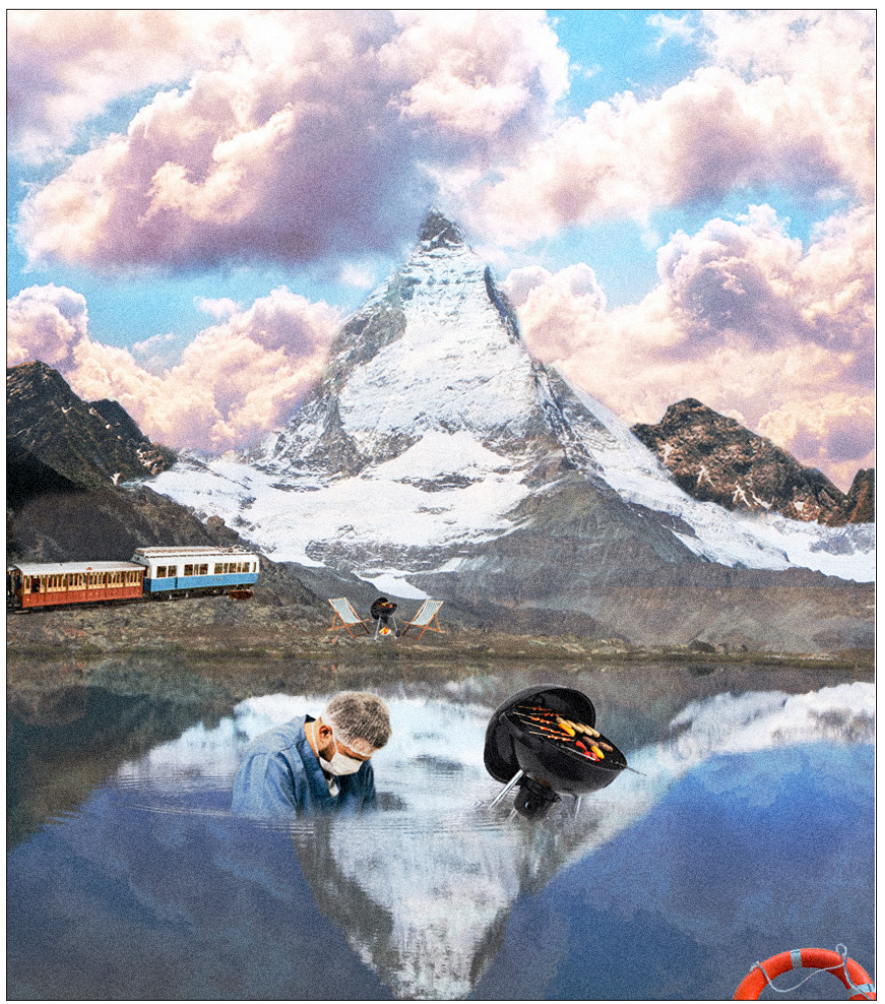

Ilustracja 2: autorka Emilia Stasiak / quarantinecollages

\section{Odcinek 3: Czy to naprawdę już koniec?}

\section{Początki euforii}

Feeria barw. Taki widok wita mnie pod supersamem. Jest poniedziałek rano, idę po mleko. Staję w pół kroku, nie rozumiejąc, co się dzieje. Po chwili myśl: prawda, rząd zarządził otwarcie fryzjerów i sklepów ogrodniczych. Znowu można sprzedawać pelargonie, sadzonki ogórka i czego tam jeszcze. Ludzie tłoczą się, cali w euforii, pakując do koszyków kolejne doniczki. Ten widok regałów z kwiatami jest jak olśnienie. Jakby ktoś przełączył telewizor z wersji czarno-białej na kolor. Jakby Szwajcaria zmieniła się w Andaluzję.

Większy porządek jest pod fryzjerem, choć i tam zbiegowisko. Na chodniku stoją grupki mężczyzn. Zamarli pod ścianą, w stanie charakterystycznego bez- 
ruchu, jakby się zawiesili. Można by pomyśleć, że to robotnicy sezonowi czekają na okazję zarobku. Na to, aż pracodawca podjedzie i rzuci z samochodu: „pięciu do ziemniaków” albo „trzech do kładzenia fug”. Trzech albo pięciu poderwie się z letargu, wskoczy na pakę i odjedzie w nieznane. Ale to Lucerna. Tłumek na chodniku czeka, żeby się ogolić i ostrzyc. Swoją drogą pod fryzjerem damskim kolejek brak.

To dopiero początek wracania do normalności, programu, który rząd ogłosił po Wielkanocy. Podano daty - kroki milowe w maju, w czerwcu, w lipcu. Gastronomia, handel, szkoły, kultura, wszystko ma znowu stać się dostępne. Na razie jest na pół gwizdka. Na razie radość jest powściągliwa.

\section{Odkrywanie świata}

Przez ostatnie miesiące po dworcu w Lucernie hulał wiatr. Ani śladu po turystach z zagranicy ani po młodzieży z okolicznych wiosek, która do miasta zjeżdża na imprezy. Zwiedzanie odwołane, imprezy też. Z pociągów w rozkładzie zostały niedobitki. Na co drugim peronie komunikat: „Pociąg odwołany z powodu pandemii”. Pojedynczy pasażerowie przemykali chyłkiem przez halę dworcową, jakby była wypełniona morowym powietrzem. Atmosferę zagrożenia potęgował widok policji, która pilnowała porządku. Pilnowała w sensie dosłownym. Bo porządek nawet aż zanadto - tu był i niewiele osób chciało go zakłócać.

Teraz ma się to zmienić. Kolejny krok ku normalności to powrót do zdrowego, tzn. starego rozkładu jazdy. I ja zbieram się na odwagę. Jako kierunek wybieram Zurych. Podróż, którą kiedyś odbywałam rutynowo, kilka razy w tygodniu, teraz przypomina wyprawę w nieznane. Towarzyszy mi lekki skok adrenaliny. $\mathrm{Na}$ peronie ktoś rozdaje chusteczki odkażające. Pasażerowie siedzą daleko od siebie. Jakby na szkolnej wycieczce ktoś ich rozsadził. Za karę, że rozrabiali. W wagonie cisza. Przez całą drogę każde skrzypniecie kół słychać będzie podwójnie. Niemrawo uśmiecham się do pasażera siedzącego dwa metry ode mnie. Uśmiecham się oczami, bo usta zasłania mi maska. Bez odpowiedzi. Czyżby strach dał się nam tak we znaki, że nawet uśmiech wydaje się niebezpieczny?

Kolejom nie jest do śmiechu, bo straty poniosły ogromne. Podobnie jak wiele firm, również i one zwróciły się do rządu o pokrycie części strat. Lista gospodarczych kolosów, które rząd musi ratować (bo to w końcu on wprowadził lockdown), jest długa. Ci mniejsi też mogą otrzymać odszkodowanie za stracony zarobek. Inni - których pracodawca jeszcze jakoś przędzie - przeszli w tryb tzw. pracy krótkiej: pracują krócej i za mniejsze pieniądze. To spotkało Narzeczonego. Nastroje są minorowe, ale najważniejsze to nie stracić pracy. W bliskim otoczeniu spotkało to aż trzy osoby.

W Zurychu spotykam się z przyjaciółką, która jest na bezrobociu. Choć ona raczej cieszy się z pandemii. Paraliż rynku sprawił, że Urząd Pracy, normalnie wy- 
magający, teraz wrzucił na luz. W końcu żadne rozmowy o pracę nie były w ostatnim czasie możliwe. Nie posiadamy się z radości: to nasze pierwsze spotkanie od wybuchu pandemii. Mimo to zachowujemy bezpieczny dystans. Na powitanie stajemy dwa metry od siebie i zaczynamy się ściskać, każda własnymi rękami. Do tego okrzyk: „Jak to fajnie się spotkać!” Żeby to oblać, idziemy na kieliszek szampana. Lokale gastronomiczne zaczęły się powoli otwierać. To też trzeba uczcić!

Stoliki rozstawione są daleko od siebie. Zamaskowany kelner przyjmuje zamówienie. Szampana podaje w rękawiczkach, mimo że to nie hotel Hilton ani nawet Bristol. W innych lokalach między stolikami stoją parawany, czasem rozwieszona jest zasłona. Zależnie od inwencji i budżetu właścicieli. Całe szczęście jest wiosna, toteż życie toczy się na ulicy. Ale i tu musi być porządek. Przed jedną z kawiarni kelnerka chodzi z centymetrem: mierzy odległość między stolikami. Teraz każdy lokal jest azylem dla wybranych. Jednego dnia, kiedy na ulicy złapie mnie ulewa, będę chciała schować się w kawiarni. Obsługa wyprosi mnie na deszcz. Przykro nam, pani się nie zmieści.

\section{Wiwat konsumpcja!}

Też w Zurychu udaję się do ulubionego serowara i centrali rybnej (po tygodniach kupowania w supermarkecie można pójść do normalnego sklepu!). To wszystko ma taki posmak, jakbyśmy spotykali się po wojnie albo innym kataklizmie - każdy small talk zaczyna się od pytania „jak przeżyliście?”. Niby jest tak, jak było, ale jednak inaczej. U serowara do lady podejść się nie da. Drogę zagradza ławka, taka jak ze zwykłego garden party. Rozmawiasz ze sprzedawcą trochę jak przez płot. U rybaka jest podobnie. Jak czapla wyciągam szyję, żeby dojrzeć flądrę i śledzia chłodzącego się w lodzie. Nie tylko ryby, ale i sprzedawca ukryty jest za warstwą szkła i plastyku. Fartuch, rękawiczki i pleksi maska na twarzy.

To plastyk jest zdecydowanym zwycięzcą pandemii. Plastyk w każdej postaci. Plastykowe rękawiczki, plastykowe zasłony na twarz, plastykowe pieniądze. Sklepy proszą o płacenie „bezdotykowo”, kartą zamiast gotówki, która nawet w kraju, gdzie pieniądz zawsze wygląda jak prosto z mennicy, zaczęła uchodzić za „niehigieniczną”. W jednym ze sklepów, zafascynowana, oglądam akrobacje towarzyszące transakcji. Sprzedawca (w plastykowych rękawiczkach) podaje mi terminal przez szmatkę. Wklepuję (niestety bez rękawiczki) numer PIN. Po zakończeniu procedury terminal zostaje opryskany z dezynfekatora i wytarty (wyszorowany!) kolejną szmatką, która za chwilę wyląduje w koszu. Niech żyje kubeł na śmieci! Ideologia no-waste ma przerwę.

Przerwę ma też filozofia „mniej znaczy więcej”. Może i pialiśmy z radości przez ostatnie miesiące, że naród przestał kupować w neurotycznym szale, ale jak otworzyli sklepy, trzeba było nadrobić zaległości. W księgarni jestem już pierwszego dnia, dziesięć minut po otwarciu. Przy drzwiach (tradycyjnie już) butelka z pły- 
nem do dezynfekcji. Dodatkowo pudełko rękawiczek. Wymytymi i ogumionymi rękami oglądam książki. Nowe wydania biorę do ręki, jakby każde było białym krukiem, który na chwilę wyleciał z bibliotecznej gabloty. Kupuję od razu dwie, z samej radości, że mogę. W tym samym tygodniu zajrzę do paru innych księgarni, dokupię jeszcze dwa tytuły. Na wszelki wypadek, cokolwiek miałoby to znaczyć.

To samo powtórzy się w odzieżowym. Pobieram numerek (w sklepie nie może przebywać więcej niż dziesięć osób) i plastykowy kaptur, na wypadek gdybym chciała coś przymierzyć. Wszystko to jest jakieś nieziemskie. Prostota środków zapobiegawczych: spryskiwacz do rąk, rękawiczki, kaptur... czy to naprawdę działa?

Przychodzi też czas na kulturę. W trybie analogowym, bo w internecie można było pójść do kina i na koncert bez opuszczania kanapy. Kino i teatr muszą jeszcze poczekać, ale muzea i galerie stoją otworem. W Bourbaki-Panorama (odpowiedniku naszej Racławickiej) seria eksponatów zalepionych taśmą. Wszystko, co interaktywne, jest wyłączone z użytku: interakcje są niebezpieczne, nawet te z muzealnym eksponatem. W muzealnym kiblu dwie umywalki też obklejone są taśmą, jak miejsce zbrodni w filmie kryminalnym. W pustym hallu ojciec z synkiem bawią się piłką. Chłopiec rzuca ją do mnie. Instynktownie łapię i odrzucam. Po chwili reakcja: czy powinnam była? Czy zostanę zrugana za zły dotyk?

\section{Bliskość wciąż podejrzana}

Powrót do konsumpcji jest prostszy niż do społeczeństwa. To jest wciąż nastawione „na dystans”. Na schodach ruchomych kobieta przede mną syczy ostrzegawczo, bo podeszłam o jeden krok za blisko. Tego rodzaju syki i obrażone chrząknięcia były mi tu do tej pory nieznane. Pewnie można zaryzykować tezę, że pandemia doprowadziła do (lekkiego) upadku obyczajów. Zwłaszcza w środkach transportu ludzie patrzą na siebie bykiem. Torby i plecaki jeżdżą już prawie legalnie na siedzeniach w autobusie, stanowiąc bufor bezpieczeństwa dla bojących się o zdrowie pasażerów.

Życie towarzyskie powoli się odradza, choć w dość specyficznej formie. Po raz pierwszy (od zimy!) idziemy na Apero do znajomych. Na szczęście mają taras, więc przy odrobinie wysiłku jesteśmy w stanie zachować dystans. Ale kiedy popsuje się pogoda i będziemy musieli wejść do domu, nagle zrobi się zbyt tłoczno. Pożegnamy się - powoli wchodzi nam to w krew - łokciem.

Podawania rąk nadal się unika. Nie wspominając już o innych kontaktach fizycznych. I właśnie przez to zwykły uścisk rąk staje się teraz niemal wywrotowy, prawie intymny, dowód prawdziwego zaufania, prawie jak seks bez kondomu. Dla osoby przywykłej do fizycznego kontaktu ten odwyk od bliskości jest wyzwaniem, zwłaszcza wśród przyjaciół i bliskich. Tworzą się różne strefy wtajemniczenia i... wykluczenia. Ta sama osoba, która dzień wcześniej wyściskała mnie na powitanie 
(jak smakuje taki uścisk po miesiącach abstynencji!), dzień później poda mi tylko łokieć. Szepnie przy tym: „Muszę uważać, tu dużo ludzi”. Trzeba dawać przykład.

Bliskość w ogóle stała się podejrzana. Korzystając z wolnego dnia, jadę w góry, popatrzeć na świat z innej (wyższej) perspektywy. Szczyt wybieram niefortunnie. Już autobus zapakowany jest na ścisk. Podobnie jest na szlaku. Ludzie tłoczą się, nawet przepychają. Gorzej niż na Giewoncie. Z góry schodzi grupa podchmielonych wyrostków, w plecaku gra muzyka. Ten z lewej zatacza się na mnie. Niestety nie wiedziałam, że cel mojej wycieczki jest ulubionym miejscem oglądania wschodu słońca. A że noce są chłodne, trzeba się czymś rozgrzać. Przy pierwszej okazji zbaczam w inną stronę. Nawet w telewizji będą mówić, że naród beztrosko popędził w góry, zapominając o środkach bezpieczeństwa. Policja nie reaguje.

Widmo policji dopada mnie gdzie indziej. Tak, wreszcie i ja idę zrobić coś $\mathrm{z}$ włosami. W malutkim salonie fryzjerka w masce na twarzy. Ale inaczej niż u Zorro, to nie oczy są zasłonięte. Ja zresztą też w masce. Takie są przepisy. Mycie głowy odbywa się jeszcze normalnie. Strzyżenie troszkę gorzej. Trudno ciąć w ciemno. W końcu dziewczyna mówi: zdejmij tę maskę, ja cię przecież w ogóle nie widzę.

Od razu robi się sympatyczniej. Dostaję nawet kawę i ciastko. Radośnie rozmawiamy o życiu w Londynie i o brytyjskim poczuciu humoru. Nagle sytuacja robi się jak z komedii: „Policja!”. Fryzjerka rzuca nożyczki i czmycha na zaplecze. Ja w popłoch. Cholera, gdzie maska?! Z podołka spadła mi na podłogę! Rzucam się pod fotel. Za chwilę ostrożnie wyjrzę przez okno. To drogówka, mówię, widząc, jak policjantka wypisuje mandat na źle zaparkowany samochód. Drogówka chyba nie kontroluje fryzjerów? Moja fryzjerka nie jest przekonana. W ostatnim czasie słyszało się historie w rodzaju: facet przyszedł do pracy z nową fryzurą. Fryzjera zamknęli. Brzmi nieprawdopodobnie. Może to legenda miejska?

\section{Leczenie ran}

W kolejną niedzielę jadę do Thun. To miasteczko jak z pocztówki: szafirowe jezioro, panorama gór jakby wycięta $\mathrm{z}$ opakowania czekolady. Właściwie to jadę służbowo, ale ponieważ jest niedziela, całość ma lekko wycieczkowy charakter. Pogoda piękna, świeci słońce, pierwszy raz po dłuższym okresie niepogody.

Spacerowiczów masa. Długi ogonek ciągnie się wzdłuż rzeki w drodze do jeziora. Ja też wędruję nabrzeżem. Po lewej stronie woda, po prawej metalowy płot, za nim pas dzikiej zieleni. Moje myśli błądzą nie wiadomo gdzie, wzrok wędruje przez kępy dzikiej roślinności za płotem. Przez tygodnie siedzenia w domu rozwinęłam pasję ogrodniczą i także tę szukania jadalnego zielska na każdej łące i poboczu drogi. Na wpół automatycznie skanuję wzrokiem, co rośnie w Thun. A nuż zobaczę coś ciekawego. 
Nagle wzrok mój pada na kawałek papieru. Zapisany i zwinięty, leży na poduszce z trawy, jakby ktoś zrzucił go z chmury. Automatycznie spoglądam w górę, chyba żeby sprawdzić, czy to niebo wysłało mi wiadomość. Ledwie dosięgam papieru przez płot. Za chwilę rozprostowany leży w mojej dłoni.

Obie strony zapisane, każda innym charakterem pisma. „Drogi/droga Nikt”, pisze autorka $\mathrm{w}$ liście skierowanym do mnie i do każdego, kto przechodzi nabrzeżem. „Myślałam, że samobójstwo rozwiąże mój problem”, relacjonuje swoje zmagania z życiem. „Chciałam czuć się potrzebna, ale wylądowałam w ciemności. Kaleczyłam się, ale to tylko zwiększało ból. »Proszę, pozwól mi umrzeć myślę o tym każdego dnia”. Czuję, jak serce zmienia mi się w ciasny węzeł. „Jestem taka samotna. Mimo że to czas pandemii, proszę, zostaw mi wiadomość. Będę tu przychodzić codziennie".

$\mathrm{Na}$ drugiej stronie odpowiedź, napisana inna ręką. Słowa otuchy, zachęty, by wytrwać. „Czasami ogarnia nas ciemność. Pamiętaj, że promyk światła dosięgnie i ciebie". Ja też dopisuję coś od siebie. Podaję kontakt, gdyby autorka chciała mnie znaleźć. Wygrzebanym z portmonetki spinaczem przypinam list do drucianego ogrodzenia i patrzę na wodę. Sądząc po tym, że litery lekko rozmył deszcz, list musi tu być od dobrych kilku dni. Czy autorka była tu, żeby sprawdzić wiadomość? Czy w ogóle jeszcze jest?

Przechodnie mijają mnie radosnym krokiem. Za chwilę i ja dołączę do nich $\mathrm{w}$ tym strumieniu niedzielnego życia. $\mathrm{Z}$ domu zadzwonię do pogotowia dla samobójców, sprawdzić, co można zrobić w sprawie nieznajomej kobiety $\mathrm{z}$ Thun. Nie mają wiele do zaproponowania. Szwajcaria ma wysoki poziom samobójstw. Dopiero co w styczniu znajomy był świadkiem tego, jak mężczyzna wskoczył pod pociąg. Czy przymusowa izolacja czasu pandemii podniesie ten poziom o poprzeczkę wyżej? To okaże się pewnie dość niedługo.

\section{Wątpliwości rosną}

W połowie czerwca po dawnych środkach bezpieczeństwa nie ma śladu. Euforia z powrotu do życia, aktywności, konsumpcji - wszystko to tłumi inne rozważania. Pewnie rozsądek też. Maski znikają z przestrzeni publicznej, tak szybko jak ostatnie łachy śniegu w Alpach. W supermarkecie płyn do dezynfekcji jeszcze stoi, ale z boku, zdetronizowany przez górę koszyków, które zachęcają do pakowania kolejnych zakupów. Otwierają się kina, lada chwila rząd pozwoli na organizację koncertów nawet na kilkaset osób. Zurych (gdzie po północy obowiązywała godzina policyjna) uwalnia życie nocne. Można bawić się do woli, na własną (a nie rządu) odpowiedzialność. I nawet nocne autobusy wróciły na ulice.

Gdzieś na boku słychać jednak pytania. I pierwsze wątpliwości. Bo jak pogodzić to, co mówią epidemiolodzy, że wirus wciąż jest wśród nas, z parciem na powrót do maksymalnej aktywności? Granice są otwarte, ale samolotów właściwie 
niet. Co i rusz telewizja bąka, że na świecie wirus nadal szaleje. Uniwersytet zapowiedział, że zajęcia jesienią będą online. Mimo tego, że teraz można imprezować pełną parą. To jak to jest $\mathrm{z}$ tą chorobą?

Zaplanowane $\mathrm{w}$ bezpiecznych odstępach czasu kroki milowe przyspieszyły tempo. Co miało się dziać w lipcu, zdarzyło się już w czerwcu. Co w czerwcu, to w maju itd. Sąsiadka na schodach wyrzeka: rząd nie kieruje się dobrem społeczeństwa, tylko gospodarki. W najgorszym okresie pandemii sprawiał wrażenie jedności, teraz każda partia ciągnie w swoją stronę. „To wszystko lobby biznesowe”, sąsiadka krzywi się z niesmakiem. „Nie lubię tego partyjniactwa”, dodaje.

Wirus wciąż jest wśród nas, nawet jeśli o nim trochę zapomnieliśmy. Na wszelki wypadek zaopatrzyłam się w kolekcję masek na twarz. Niewiele osób podziela mój entuzjazm dla tego dodatku do stroju. Członkowie rządu też nie pokazali się $\mathrm{w}$ masce. Szwajcaria cały czas wstrzymuje się z wprowadzeniem nakazu noszenia ich, choćby w transporcie publicznym (choć konduktorzy apelowali). Rząd pozostał przy zaleceniu, że nosić... warto: „Szwajcarom nie należy zakazywać. Liczymy na rozsądek obywateli”. W gazecie pojawiła się debata, dlaczego rozsądek pozostaje głuchy i ludzie nie zakładają maski. Wygrała teoria, że to dlatego, że maska bardziej chroni innych niż nas samych. Po co się wysilać dla innych, głosił autor, rekonstruując statystyczną logikę mieszkańca kraju. To by przeczyło wizji solidarnych obywateli, którzy troszczą się o siebie nawzajem.

Znajoma - młoda, choć z grupy ryzyka - spytała mnie niedawno, czy ma prawo wymagać, by ludzie nosili maski, żeby osoby z mniejszości - takie jak ona chronić przed wirusem. Jasne, że tak. Mniejszości się chroni. Czy to nie jest jakaś żelazna zasada demokracji? Ale jak choroby nie widać (a i słychać o niej też niewiele), wszelkie środki prewencyjne wydają się zbędne. Sensowność całego lockdownu zaczęła być podawana $\mathrm{w}$ wątpliwość. Ale to tak jak w ogóle z prewencją, mówi ta sama znajoma, która notabene pracuje w ośrodku pomocy narkomanom. Skuteczność prewencji jest jednocześnie jej gwoździem do trumny. Ludzie skłonni są zapominać, że problemy lubią wracać.

\section{Odwrót od rzodkiewki}

Zaległości w kontaktach towarzyskich nadrabiam, gdzie się da. Zresztą nie tylko kontaktów jestem spragniona. Nieprzewidywalności, beztroski, śmiechu. Przypadkowych interakcji, small talków, wszelkich elementów, który wychodziłyby poza koronarutynę. Powrót do życia towarzyskiego oznacza, że rzodkiewki popadają w zapomnienie. Ogród już nie jest kompensatą braku towarzystwa. To samo dotyczy sklepów spożywczych. Podczas lockdownu kupienie nawet jednej cebuli było dobrą wymówką, żeby wyjść z domu. Co ja zrobię, że potrzebuję ludzi, interakcji, nawet w minimalnym stopniu. Siedzenie w domu to nie dla mnie. Ale dzięki home office odkryłam, że sąsiad z drugiego piętra maltretuje dorosłą córkę. Rząd 
miał chyba rację, mówiąc, że zakaz wychodzenia z domu wpłynie na przyrost przemocy domowej.

Patrząc na kwitnący ogród, myślę: Całe szczęście, że pandemia wybuchła na wiosnę. A kiedy będzie druga fala? Od jakiegoś czasu do mediów przebijają się wiadomości o ponownym wzroście liczby zachorowań. Niby niewiele, ale jednak: sto, sto kilkadziesiąt na dzień. To i tak luksus w porównaniu do krajów, które akurat przeżywają masową tragedię i śmierć tysięcy ludzi. Prędzej czy później choroba dociera wszędzie. Cóż, efekt globalizacji.

W obliczu rosnącej liczby nowych zachorowań rząd robi jednak ten radykalny krok, z którym tyle się wstrzymywał. Maski będą obowiązywać, przynajmniej w transporcie publicznym. Teraz kiedy jadę pociągiem, patrzą na mnie same oczy. Oczy i tylko oczy. Zwielokrotniony big brother i big sister (kosmetyczka w drogerii próbuje mnie namówić na prelekcje o podkreślaniu oczu: „kiedyś były zwierciadłem duszy, teraz głównym medium komunikacji” - mówi z przekonaniem).

W kraju, w którym nie chcą burek i czadorów (choć poza niektórymi turystkami z krajów arabskich nikt ich nie nosi), a inne sposoby zasłaniania twarzy, na demonstracji czy meczu, też są przez państwo niezbyt lubiane, obowiązek zasłaniania twarzy brzmi jak złośliwość losu. 